\title{
KENYAMANAN DAN KEPERCAYAAN KONSUMEN BLIBLI.COM BERPENGARUH TERHADAP KEPUTUSAN PEMBELIAN ONLINE
}

\author{
Lia Siti Asyifa \\ Universitas Pendidikan Indonesia \\ lia.siti@student.upi.edu \\ Agus Rahayu \\ Universitas Pendidikan Indonesia \\ Agusrahayu@upi.edu
}

\begin{abstract}
Purpose - The purpose of this paper was to be found out the influence of shopping enjoyment and consumer trust towards online purchase decision on member of Fan page Facebook Blibli.com

Design/methodology/approach - This type of research used are descriptive, verifikatif. The method used was explanatory survey with simple random sampling techniques and sample number of 165 respondents. Data analysis technique used is a path with equal tools computer software SPSS 22.

Findings - shopping enjoyment and consumer trust has influenced on purchase decisions online simultaneously and partially.

Originality/value - The paper provides a basis to understand the issues of purchasing decisions on member of fan page facebook Blibli.com. The difference of this study with earlier research on objects that are the variable used supporting the theory as well as the different references used by previous researchers.
\end{abstract}

Keywords:Shopping Enjoyment, Consumer Trust, Purchase Decision, Purchase Decision Online

Article Type: Research Paper

\section{PENDAHULUAN}

Keputusan pembelian online adalah proses seleksi yang megkombinasikan pengetahuan untuk mengevaluasi dua atau lebih perilaku alternatif, danatau memilih salah satu diantaranya yang kuat hubungannya dengan karakter personal, vendor/service, website quality, sikap pada saat pembelian, maksud untuk membeli online, dan pengambilan keputusan (Andrade 2000; Cho et al., 2001; Jarvenpaa et al., 2000; Lee et al., 2000). Proses membeli melalui media internet terjadi ketika konsumen yang berpotensial menggunakan internet dan mencari informasi yang berkaitan dengan barang atau jasa yang mereka butuhkan.

E-commerce saat ini mulai berkembang dengan pesat di Indonesia yaitu dengan munculnya situs jual beli online. Pertumbuhan pengguna internet di Indonesia begitu pesat sehingga marketer melihat banyak potensi dari masalah ini. Marketer mulai menaruh perhatian pada pemanfaatan channel digital sebagai salah satu wadah berkomunikasi dan menaikkan penjualan. Masyarakat dan konsumen pun mulai menggeser pola keseharian dalam mengkonsumsi sebuah produk maupun jasa. Berikut merupakan nilai penjualan e-commerce di Indonesia dalam Tabel 1
TABEL 1

NILAI DAN TRANSAKASI E-COMMERCE DI INDONESIA

\begin{tabular}{ccc}
\hline TAHUN & $\begin{array}{c}\text { Jumlah Transaksi } \\
\text { (Dalam Juta } \\
\text { Rupiah) }\end{array}$ & $\begin{array}{c}\text { Nilai } \\
\text { Transaksi } \\
\text { (Juta USD) }\end{array}$ \\
2011 & 3.746 & 67 \\
2012 & 7.176 & 144 \\
2013 & 12.103 & 266 \\
2014 & 19.109 & 478 \\
2015 & 28.648 & 776 \\
\hline
\end{tabular}

Sumber: majalah SWA 01 XXX 12015 (data diolah).

Setiap tahun jumlah nilai penjualan $e$ commerce semakin meningkat. Peningkatan ini terjadi seiring dengan bertambahnya jumlah pembelanja online di Indonesia. Sebagai negara dengan populasi terbesar keempat di dunia, Indonesia memiliki penetrasi pengguna internet yang relatif rendah, yakni sekitar $31 \%$ atau sekitar 75 juta penduduk per 2013. Kemudian jumlah pengguna internet Indonesia diprediksi akan menyentuh angka hingga 100 juta per 2016, dengan angka penetrasi belanja online yang diharapkan turut meningkat. (Ystats.com dalam Majalah Marketing, 2015: 58).

Budaya belanja online semakin diminati masyarakat Indonesia. Hal tersebut didukung oleh 
hasil riset yang diungkapkan oleh Philip Yen (Group Head Emerging Payment Asia Pasific Middle East Africa Master Card Worldwide) bahwa kecenderungan masyarakat Indonesia untuk berbelanja online mulai meningkat. Laporan Nielsen Indonesia yang dipublikasikan triwulan pertama tahun 2014, konsumen Indonesia mulai menyukai belanja online, mereka senang membaca ulasan dan mencari informasi mengenai produk dan jasa yang dibutuhkan. BMI menyatakan bahwa pada tahun 2014 pengguna belanja online mencapai $24 \%$ dari jumlah pengguna internet di Indonesia. Riset tersebut di lakukan di 10 kota besar di Indonesia terhadap 1.213 orang dengan usia antara 18-45 tahun melalui metode phone survey.

Terdapat beberapa situs online shop di Indonesia yang diminati masyarakat. Banyaknya toko-toko online yang terus bermunculan terutama pada platform media sosial dan instant messaging menciptakan persaingan diantara pelaku bisnis online. Toko online yang dikelola oleh perorangan tersebut menjadi sebuah ancaman bagi situs belanja online yang berbasis business to consumer karena dapat mengancam kelangsungan perusahaan. Beberapa situs seperti Tokobagus.com dan Berniaga.com saat ini berubah menjadi OLX.co.id. Kedua situs tersebut melakukan merger sebagai bentuk kerjasama untuk menghindari kebangkrutan. Semakin bertambahnya toko-toko online memberikan banyak pilihan bagi konsumen pada saat membuat sebuah keputusan pembelian. Belanja berbagai kebutuhan saat ini tersedia secara online dan tersedia berbagai penawaran pada masingmasing toko online. Namun banyaknya pilihan tersebut bukan berarti mempermudah saja, tetapi akan muncul masalah bagi konsumen untuk memutuskan membeli produk yang mereka butuhkan dengan berbagai penawaran yang diberikan.

Blibli.com merupakan situs belanja online yang berada dibawah naungan PT Global Digital Niaga yang merupakan salah satu pelopor online shopping mall, dan berkomitmen memberikan pengalaman berbelanja online yang aman, nyaman, mudah menyenangkan, dimana saja dan kapan saja. (www.blibli.com. Akses: 14:48 WIB.Senin, 1 Ferbruari 2016). Namun, hal ini tidak sejalan antara visi dengan kenyataan dilapangan. Blibli.com memiliki jumlah pengunjung yang paling rendah dibanding dengan online shop lainnya, seperti yang dijelaskan pada Tabel 2. Selain itu, berdasarkan data market share blibli.com memiliki presentase rendah. Hal ini berarti mempengaruhi jumlah pembelian yang dilakukan konsumen dalam berbelanja secara online pada situs Blibli.com. Berikut data digital marketing award yang akan dituangkan dalam Tabel 2

TABEL 2

DATA MARKET SHARE ONLINE SHOP TAHUN 2013-2015

\begin{tabular}{clccc}
\hline \multirow{2}{*}{ No. } & \multirow{2}{*}{ Merek } & \multicolumn{3}{c}{ Market Share } \\
\cline { 3 - 5 } & & $\mathbf{2 0 1 5}$ & $\mathbf{2 0 1 4}$ & $\mathbf{2 0 1 3}$ \\
\hline 1 & Lazada.co.id & $38,8 \%$ & $29,8 \%$ & $25 \%$ \\
2 & OLX.co.id & $33,5 \%$ & $31 \%$ & $30,5 \%$ \\
3 & Blibli.com & $3,8 \%$ & $8,8 \%$ & $20 \%$ \\
4 & Bukalapak.com & $5,9 \%$ & $22.3 \%$ & $15 \%$ \\
5 & Tokopedia.com & $4,6 \%$ & $8,1 \%$ & $9,5 \%$ \\
\hline
\end{tabular}

Sumber: Majalah SWA 24, 2015 (data diolah)

Berdasarkan Tabel 2 menunjukkan bahwa penjualan pada Blibli.com memiliki persentase paling rendah pada tahun 2012 dibanding dengan merek lainnya dengan $3,8 \%$. Hal ini terjadi karena banyaknya keluhan konsumen mengenai pelayanan pada Blibli.com, sehingga keputusan konsumen untuk melalukan pembelian pada situs Blibli.com menjadi menurun. Hal ini diperkuat, berdasarkan data dari testimoni konsumen Blibli.com terhadap layanan Blibli.com yang telah diolah oleh penulis, terlihat bahwa masalah seperti pengadaan barang, ketepatan pengiriman, dan respon customer service menjadi beberapa masalah yang dikeluhkan oleh konsumen Blibli.com. Oleh karena itu, sebelum melakukan pembelian, konsumen akan melewati beberapa tahapan dalam proses pengambilan keputusan pembelian.

Dampak yang terjadi apabila suatu perusahaan memiliki keputusan pembelian yang rendah adalah berkurangnya jumlah konsumen serta penurunan jumlah penjualan. Keputusan pembelian adalah pemilihan dari dua atau lebih alternatif pilihan keputusan pembelian. Artinya bahwa seseorang dapat membuat keputusan, haruslah tersedia beberapa altenatif pilihan. Keputusan untuk membeli dapat mengarah kepada bagaimana proses dan pengambilan keputusan tersebut itu dilakukan (Schiffman, Kanuk, 2004: 547). Proses pengambilan keputusan konsumen bukanlah berakhir dengan pembelian, namun berlanjut hingga pembelian tersebut menjadi pengalaman bagi konsumen dalam menggunakan produk yang dibeli tersebut. Pengalaman itu akan menjadi bahan pertimbangan untuk pengambilan keputusaan pembelian di masa depan (Ma'ruf, 2005:14). Konsumen memiliki sikap beragam dalam memandang atribut yang relevan dan penting menurut manfaat dan yang mereka cari. Kumpulan keyakinan atas merek tertentu membentuk citra merek, yang disaring melalui dampak persepsi selektif, distorsi selektif dan ingatan selektif (Kotler, 2016:223). 
Pendekatan atau grand theory yang digunakan dalam penelitian ini adalah teori perilaku konsumen, karena fokus dari perilaku konsumen adalah bagaimana individu membuat keputusan untuk menggunakan sumber daya mereka yanag telah tersedia untuk mengkonsumsi sebuah barang. Ada dua faktor dasar yang mempengaruhi perilaku konsumen yaitu faktor eksternal dan internal. Keputusan pembelian dari pembeli sangat dipengaruhi oleh faktor kebudayaan, sosial, pribadi dan psikoligi dari pembeli. Keputusan pembelian juga dipengaruhi oleh ciri-ciri kepribadiannya, termasuk usia, pekerjaan, keadaan ekonomi. Perilaku konsumen akan menentukan proses pengambilan keputusan dalam melakukan pembelian (Kotler, 2016).

Untuk mengetahui faktor apa saja yang mempengaruhi konsumen dalam melakukan keputusan pembelian maka dilakukan sebuah uji penelitian kecil terhadap responden. Menggunakan teori menurut Katawetawaraks dan Wang (2011:68) yang terdiri dari kenyamanan, informasi, ketersediaan barang dan jasa, serta efisinsi biaya dan waktu.

\section{TABEL 3 \\ FAKTOR-FAKTOR YANG MEMPENGARUHI KEPUTUSAN PEMBELIAN PADA SITUS BLIBLI.COM}

\begin{tabular}{|c|c|c|c|c|}
\hline No. & $\begin{array}{c}\text { Dimensi } \\
\text { Keputusan } \\
\text { Pembelian }\end{array}$ & Ukuran & Setuju & $\begin{array}{l}\text { Tidak } \\
\text { Setuju }\end{array}$ \\
\hline \multirow[t]{4}{*}{1} & Kenyamanan & Acces & 24 & 6 \\
\hline & & Search & 16 & 14 \\
\hline & & Possession & 14 & 16 \\
\hline & & Transaction & 14 & 16 \\
\hline \multirow[t]{4}{*}{2} & Informasi & Product & 22 & 8 \\
\hline & & Review & 16 & 14 \\
\hline & & Customer & & \\
\hline & & Reviews & & \\
\hline \multirow[t]{4}{*}{3} & Ketersediaan & Products & 15 & 15 \\
\hline & barang dan jasa & availability & 12 & 18 \\
\hline & & Services & & \\
\hline & & availability & & \\
\hline \multirow[t]{4}{*}{4} & Efisiensi biaya & Cost Efficiency & 13 & 17 \\
\hline & dan waktu & Time & 13 & 17 \\
\hline & & Efficiency & & \\
\hline & & Total & $53 \%$ & $47 \%$ \\
\hline
\end{tabular}

Sumber: Pra Penelitian terhadap 30 konsumen Blibli.com, tanggal 29 April 2016

Berdasarkan Tabel 3 menunjukkan hasil pra penelitian faktor-faktor yang mempengaruhi keputusan pembelian. Hasil menunjukkan dimensi dari keputusan pembelian yang dilakukan mendapatkan respon yang cukup positif dari responden. Besaran faktor-faktor yang mempengaruhi keputusan pembelian yang dipilih oleh konsumen ialah sebanyak 53 persen memilih setuju. Sedangkan 15 persen dari pilihan konsumen memilih tidak setuju dan ukuran yang paling menyumbang pilihan tidak setuju adalah acces dan product review. Responden sadar akan dorongan untuk memiliki barang dengan sejumlah informasi produk yang mereka punya untuk memilih barang yang diinginkan. Keputusan pembelian tidak hanya informasi yang mereka dapat tetapi kepercayaan dan kenyamanan dapat juga memberikan perhatian yang lebih bagi konsumen karena dengan kepercayaan yang tinggi serta kenyamanan konsumen dalam melakukan pembelian dapat mengubah pelanggan yang puas menjadi loyal. Hal ini sesuai dengan penelitian Bruner dan Kumar, 2005; Dahlberg, Mallat, dan Oorni, 2003 yang menunjukkan bahwa keyakinan tentan trust (kepercayaan) dan enjoyment (kenyamanan) merupakan faktor utama yang mempengaruhi keputusan pembelian online.

Permasalahan-permasalahan seperti ini tentunya dapat berdampak kepada kepercayaan konsumen Blibli.com. Berdasarkan data testimoni konsumen Blibli.com ini, maka masalah kepercayaan menjadi salah satu hal utama yang harus diperbaiki oleh Blibli.com. Berikut ini merupakan data transaksi dari Blibli.com bulan 2013-2016 yang disajikan pada Tabel 1.4

TABEL 4

DATA TRANSAKSI BLIBLI.COM 2013-2016

\begin{tabular}{ccccc}
\hline Bulan & $\mathbf{2 0 1 6}$ & $\mathbf{2 0 1 5}$ & $\mathbf{2 0 1 4}$ & $\mathbf{2 0 1 3}$ \\
\hline Januari & 5.862 & 6.211 & 6.232 & 2.345 \\
Februari & 5.298 & 5.498 & 5.576 & 5.324 \\
Maret & 5.477 & 5.987 & 6.685 & 3.563 \\
April & 6.856 & 6.943 & 8.518 & 5.436 \\
Mei & 4.723 & 5.423 & 7.978 & 6.344 \\
Juni & 7.584 & 7.784 & 7.784 & 5.582 \\
Juli & 5.367 & 5.567 & 6.014 & 6.232 \\
Agustus & & 4.987 & 4.989 & 5.576 \\
September & & 7.896 & 8.536 & 6.685 \\
Oktober & & 7.498 & 7.958 & 8.518 \\
November & & 6.879 & 7.798 & 7.978 \\
Desember & & 4.657 & 5.857 & 7.784 \\
\hline Suber: Blib & & & &
\end{tabular}

Sumber: Blibli.com

Tabel di atas terlihat bahwa transaksi yang terjadi di situs Blibli.com mengalami penurunan dari bulan September 2015 sampai bulan Desember 2015. Ini membuktikan bahwa situs Blibli.com kalah bersaing dengan onlineshop sejenis dan faktor lainnya adalah semakin banyaknya situs online shop baru yang lebih memberikan kemudahan dalam bertransaksi. Elissa (2013) menyatakan bahwa dari beberapara faktor yang mempengaruhi keputusan pembelian, faktor kepercayaan konsumen melalui e-mail secara signifikan berpengaruh langsung terhadap keputusan pembelian.Sedangkan Sularto (2004) mengatakan bahwa faktor privasi, kepercayaan 
dan pengalaman terbukti telah menjadi faktor utama yang mempengaruhi konsumen dalam melakukan pembelian melalui internet.

Gefen dan Straub (2004) menjelaskan bahwa semakin tinggi derajat kepercayaan konsumen, semakin tinggi tingkat pembelian niat konsumen. Kepercayaan perlu ada ketika menempatkan pesanan online dan ketika pelanggan mengirimkan informasi keuangan daan data pribadi lainnya dalam melakukan transaksi keuangan. Jika dalam hal tersebut terdapat banyaknya keluhan mengenai hal tersebut, maka akan menimbulkan ketidaknyamanan pelanggan dalam melakukan transaksi. Maka kenyamanan dalam berbelanja pun perlu menjadi faktor yang harus dipertimbangkan bagi Blibli.com.

Kenyamanan telah diidentifikasi sebagai penentu penting mengapa konsumen memutuskan untuk membeli. Koufaris (2002) dan Childers et al. (2001) menemukan bahwa shopping enjoyment sangat memperkirakan niat untuk kembali ke situs web dan mengukur dimensi dalam hal pengalaman yang asyik, menyenangkan, menarik dan nyaman. Jika konsumen merasa senang dan tumbuh rangsangan selama pengalaman belanja mereka, mereka sangat mungkin untuk terlibat dalam perilaku belanja berikutnya, mereka menelusuri lebih lanjut, terlibat dalam pembelian tidak terencana, dan mencari lebih banyak produk dan kategori.

Tujuan penelitian ini adalah: 1) untuk mengetahui kenyamanan konsumen melakukan pembelian secara online pada situs Blibli.com, 2) untuk mengetahui kepercayaan konsumen melakukan pembelian secara online pada situs Blibli.com, 3) untuk mengetahui keputusan pembelian online pada situs Blibli.com, dan 4) untuk menganalisis besarnya pengaruh kenyamanan dan kepercayaan konsumen terhadap keputusan pembelian secara online pada situs Blibli.com

\section{KAJIAN PUSTAKA}

Strategi pemasaran yang tepat merupakan kombinasi dari elemen-elemen pemasaran yang dirancang untuk memperoleh pasar sasaran. Menurut Kotler dan Amstrong (2014:27) pemasaran adalah sebuah proses yang dilakukan perusahaan untuk membangun dan menciptakan nilai bagi pelanggan yang bertujuan untuk membangun hubungan yang kuat dengan para pelanggan dan mendapatkan nilai dari pelanggan itu sendiri untuk perusahaan sebagai balasan. Salah satu kajian dalam pemasaran adalah perilaku konsumen yang didefinisikan sebagai perilaku menggunakan, mengevaluasi dan menghabiskan produk dan jasa yang konsumen harapkan akan memuaskan kebutuhan konsumen (Schiffman dan Kanuk, 2010:23). Perilaku konsumen dipengaruhi oleh faktor eksternal dan internal, faktor eksternal terdiri dari cultural dan social factor, sedangkan faktor internal terdiri dari personal dan psychological factor. Faktor psikologi terdiri dari motivasi, persepsi, pembelajaran serta keyakinan dan sikap (Kotler dan Armstrong, 2014:159).

Transaksi jual beli dalam konteks online, mengharuskan penjual menciptakan keunggulan yang dapat membuat konsumen berminat untuk membeli produk yang dijual. Menciptakan keunggulan tersebut penjual perlu mengetahui bagaimana perilaku konsumen yang ada dipasar online. Ada beberapa hal pada perilaku konsumen dengan faktor-faktor yang mempengaruhi konsumen itu sendiri. Faktor psikologis merupakan pemilihan pembelian seseorang yang dipengaruhi oleh empat faktor psikologi utama salah satunya keyakinan dan sikap.Sikap sendiri terdiri dari atribut, kepercayaan dan manfaat (Solomon (2013:152). Kepercayaan merupakan salah satu bagian penting dalam pemasaran secara online, karena dengan kepercayaan konsumen akan merasa lebih nyaman dan aman untuk berbelanja secara online. Faktor-faktor yang mempengaruhi kepercayaan meliputi duavariabel yaitu: trusting beliefe dan trusting intention (Mcknight dan Chervany, 2001).

Kajian online shopping enjoyment sendiri berawal dari faktor motivasi. Proses motivasi terjadi karena adanya kebutuhan, keinginan maupun harapan yang tidak terpenuhi yang menyebabkan timbulnya ketegangan. Terdapat unsur-unsur yang terlibat dalam proses motivasi, yaitu kebutuhan, perilaku dan tujuan. Tujuan merupakan sesuatu yang akan dicapai oleh konsumen sebagai hasil atas tindakan yang dilakukan. Konsumen dapat dibagi dalam hal orientasi belanja mereka, atau sikap umum tentang belanja. Orientasi ini dapat bervariasi, tergantung pada tertentu kategori produk dan jenis toko dipertimbangkan. Penelitian yang dilakukan oleh Seock dan Bailey (2008:118-119) mengemukakan bahwa 7 jenis orientasi belanja yang terdiri dari: (1) Shopping Enjoyment, (2) Brand and Fashion Conscious Shopper, (3) Price Conscious, (4) Shopping Confidence, (5) Convenience/Time Conscious, (6) In-Home Shopping, (7) Brand/Store Loyalty.

Shopping enjoyment atau kenikmatan belanja diartikan sebagai kesenangan yang diperoleh dari proses belanja (Kwek et al., 2010:8). Konsumen yang masuk dalam kategori enjoy, akan mencapai kesenangannya dengan menghabiskan waktu untuk melakukan browsing produk yang diinginkannya. Suasana hati yang baik merupakan salah satu alat ukur dari shopping enjoyment (Seock dan Bailey, 2008:118-119). Terdapat tiga dimensi yang mempengaruhi 
shopping enjoyment, yaitu: 1) consumer empowerment orientation dan interactivity, 2) user generated content dan 3) attractiveness (Lee Hao et al., 2014:357-358).

Periset pemasaran mengembangkan model tingkat proses keputusan pembelian. Konsumen akan melalui lima tahap yaitu 1) pengenalan masalah, 2) pencarian informasi, 3) evaluasi alternatif, 4) keputusan pembelian dan 5) perilaku pasca pembelian. Pada tahap evaluasi alternatif konsumen membuat peringkat produk dan membentuk minat pembelian (Kotler dan Keller, 2016:176). Secara umum, keputusan pembelian konsumen akan membeli produk yang paling disukai, tetapi dua faktor bisa datang antara minat pembelian atau keputusan pembelian. Pengambilan keputusan konsumen didefinisikan sebagai pola perilaku konsumen itu dilanjutkan, menentukan dan mengikuti proses pengambilan keputusan untuk akuisisi kebutuhan memuaskan produk, ide atau jasa (Kawee Boonlertvanic, 2009:58).

Dimensi yang dapat mempengaruhi minat pembelian yaitu: 1) convenience (kenyamanan), 2) information (informasi), 3) available product and service (ketersediaan barang dan jasa), dan 4) cost and time efficiency (efisiensi biaya dan waktu) (Katawetawaraks dan Wang, 2011:68).

\section{METODE PENELITIAN}

Penelitian ini dilakukan untuk mengetahui pengaruh kenyamanan dan kepercayaan konsumen terhadap keputusan pembelian pada anggota fan page Facebook Blibli.com. Variabel bebas (independent variable) atau variabel eksogen yang terdapat pada penelitian ini yaitu kenyamanan $\left(X_{1}\right)$ dengan dimensinya 1) consumer empowerment orientation dan interactivity, 2) user generated content dan 3) attractiveness. Kepercayaan $\left(\mathrm{X}_{2}\right)$ dengan dimensinya yang mencakup (1) trusting beliefe dan (2) trusting intention. Sedangkan variabel terikat (dependent variable) atau variabel endogen pada penelitian ini yaitu keputusan pembelian dengan dimensinya yang mencakup (1) convenience (kenyamanan), (2) information (informasi), (3) available product and service (ketersediaan barang dan jasa) dan 4) cost and time efficiency (efisiensi biaya dan waktu).

Objek/unit analisis pada penelitian ini yaitu anggota fan page Facebook Blibli.com. Penelitian ini dilakukan pada kurun waktu kurang dari satu tahun, sehingga teknik pengumpulan data yang digunakan pada penelitian ini adalah crosssectional method. Teknik yang digunakan dalam penelitian ini adalah teknik propability yaitu simple random dengan jumlah sampel sebanyak 165 responden. Teknik pengumpulan data yang digunakan adalah studi kepustakaan, studi lapangan dengan penyebaran kuesioner, dan studi literatur. Sedangkan teknik analisis data yang dilakukan adalah analisis deskriptif dan verifikatif. Analisis data verifikatif menggunakan Path Analysis dengan bantuan software SPSS 22 for windows.

\section{HASIL PENELITIAN DAN PEMBAHASAN}

Pengujian hipotesis penelitian ini dilakukan untuk mengetahui besarnya pengaruh kenyamanan dan kepercayaan konsumen terhadap keputusan pembelian. Pengujian hipotesis secara simultan dilakukan menggunakan teknik analisis jalus (Path Analysis). Pengujian hipotesis penelitian ini dilakukan untuk mengetahui besarnya pengaruh kenyamanan dan kepercayaan konsumen terhadap keputusan pembelian. Konseptual diagram untuk hipotesis tersebut ada pada gambar berikut:

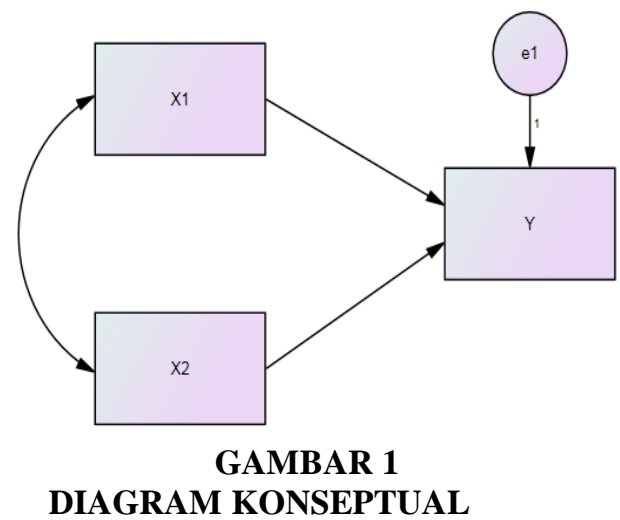

\section{Hasil Pengujian Secara Simultan}

Hipotesis penelitian ini adalah kenyamanan $\left(\mathrm{X}_{1}\right)$ dan kepercayaan konsumen $\left(\mathrm{X}_{2}\right)$ berpengaruh terhadap keputusan pembelian (Y). Hipotesis ini diuji secara simultan maupun parsial dengan menggunakan SPSS 22 for windows. Adapun hasil pengujian hipotesis secara keseluruhan (simultan) dapat dilihat pada Tabel 4.19 berikut ini:

TABEL 5

PENGUJIAN SECARA SIMULTAN

\begin{tabular}{ccccc}
\hline $\begin{array}{c}\text { Hipotesis } \\
\text { Alternatif }\end{array}$ & F hitung & F tabel & Keputusan & Kesimpulan \\
\hline $\begin{array}{c}\mathrm{X}_{1} \text { dan } \mathrm{X}_{2} \\
\text { berpengaruh } \\
\text { terhadap Y }\end{array}$ & 94.626 & 3,08 & $\begin{array}{c}\text { Ho } \\
\text { ditolak }\end{array}$ & Signifikan \\
\hline
\end{tabular}

Sumber: Hasil Pengolahan Data 2016

Tabel di atas menunjukkan pengujian untuk uji $\mathrm{F}$ yang diambil dari Anova dengan tingkat probabilitas $(\mathrm{Sig})=0,000$ karena $\mathrm{Sig} \leq 0,05$ maka keputusannya adalah $\mathrm{H}_{0}$ ditolak, artinya secara simultan (keseluruhan) terdapat pengaruh yang positif antara pengaruh kenyamanan dan kepercayaan konsumen terhadap keputusan 
pembelian produk di social commerce pada anggota fan page facebook Blibli.com.

\section{Hasil Pengujian Secara Parsial}

Hasil pengujian secara keseluruhan memberikan hasil yang signifikan. Maka untuk mengetahui variabel bebas yang berpengaruh nyata terhadap $\mathrm{Y}$ dapat dilanjutkan dengan pengujian secara parsial. Berikut matrik korelasi dapat dilihat pada Tabel 6 berikut:

TABEL 6

MATRIKS KORELASI ANTARA KENYAMANAN DAN KEPERCAYAAN KONSUMEN TERHADAP KEPUTUSAN PEMBELIAN

\begin{tabular}{cccc}
\multicolumn{4}{c}{ KEPUTUSAN PEMBELIAN } \\
\hline Variabel & $\mathbf{X}_{\mathbf{1}}$ & $\mathbf{X}_{\mathbf{2}}$ & $\mathbf{Y}$ \\
\hline $\mathbf{X}_{\mathbf{1}}$ & 1 & 0,616 & 0,681 \\
$\mathbf{X}_{\mathbf{2}}$ & 0,616 & 1 & 0,635 \\
$\mathbf{Y}$ & 0,681 & 0,635 & 1
\end{tabular}

Sumber: Hasil Pengolahan Data 2016

Keterangan:

$\mathrm{X}_{1} \quad$ : Variabel Kenyamanan

$\mathrm{X}_{2} \quad$ : Variabel Kepercayaan Konsumen

$\mathrm{Y} \quad$ : Variabel Keputusan Pembelian

Tabel 6 menunjukkan hubungan dari setiap variabel yang terdiri dari kenyamanan dan kepercayan konsumen. Berdasarkan hasil matriks korelasi antara kinerja kenyamanan dan kepercayan konsumen terhadap keputusan pembelian diperoleh hasil korelasi secara berurutan yaitu pada anggota fan page facebook Blibli.com kenyamanan $(0,681)$ dan kepercayaan konsumen (0,635). Sedangkan antara kenyamanan dan kepercayan konsumen memiliki korelasi sebesar $(0,616)$. Berikut Tabel 7 yang menunjukkan hasil perhitungan dari pengujian parsial:

TABEL 7

PENGUJIAN PARSIAL

\begin{tabular}{cccccc}
\hline No & Hipotesis & $\begin{array}{c}\text { Koefisien } \\
\text { Jalur }\end{array}$ & t hitung & t tabel & Keputusan \\
\hline 1 & $\begin{array}{c}\mathrm{X}_{1} \\
\text { berpengaruh } \\
\text { terhadap Y } \\
\mathrm{X}_{2}\end{array}$ & 0,467 & 6,2891 & 1,66 & $\begin{array}{c}\text { Ho } \\
\text { ditolak }\end{array}$ \\
2 & $\begin{array}{c}\text { berpengaruh } \\
\text { terhadap Y }\end{array}$ & 0,348 & 5,138 & 1,66 & $\begin{array}{c}\text { Ho } \\
\text { ditolak }\end{array}$ \\
\hline
\end{tabular}

Sumber: Hasil Pengolahan Data 2016

Berdasarkan tabel di atas dapat dilihat bahwa nilai $\mathrm{t}$ hitung untuk variabel $\mathrm{X}_{1}$ dan $\mathrm{X}_{2}$ lebih besar daripada $t$ tabel, hal tersebut diartikan bahwa kedua variabel memberikan pengaruh yang signifikan terhadap Variabel Y. Pengaruh kenyamanan $\left(\mathrm{X}_{1}\right)$ dan kepercayaan konsumen $\left(\mathrm{X}_{2}\right)$ berpengaruh terhadap keputusan pembelian (Y) adalah signifikan. Diagram jalur pada hipotesis tersebut dapat digambarkan sebagai berikut:

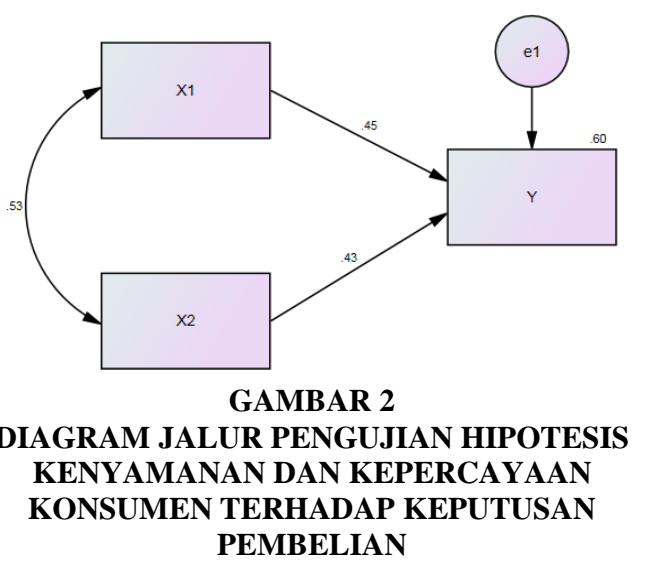

Keterangan:

$\mathrm{X}_{1} \quad$ : Variabel Kenyamanan

$\mathrm{X}_{2} \quad$ : Variabel Kepercayaan Konsumen

Y : Variabel Keputusan Pembelian

$\varepsilon \quad$ : Epsilon (variabel lain yang mempengaruhi)

Berdasarkan diagram jalur pengujian hipotesis pada Gambar 2 maka dilakukan perhitungan untuk mengetahui pengaruh langsung dan tidak langsung antara dimensi-dimensi yang disajikan dalam Tabel 8 berikut ini:

TABEL 8

HASIL PENGUJIAN KOEFISIEN JALUR PENGARUH LANGSUNG DAN TIDAK LANGSUNG

\begin{tabular}{|c|c|c|c|c|}
\hline \multirow[t]{2}{*}{ Variabel } & \multirow{2}{*}{$\begin{array}{c}\text { Pengaruh } \\
\text { Langsung } \\
\text { terhadap } \\
\text { Y }\end{array}$} & \multicolumn{2}{|c|}{$\begin{array}{c}\text { Pengaruh } \\
\text { Tidak } \\
\text { Langsung } \\
\text { Melalui } \\
\end{array}$} & \multirow[t]{2}{*}{ Total } \\
\hline & & $\mathbf{X}_{1}$ & $\mathbf{X}_{2}$ & \\
\hline $\mathbf{X}_{1}$ & 0,218 & - & 0,10 & 0,318 \\
\hline $\mathbf{X}_{2}$ & 0,121 & 0,10 & - & 0,221 \\
\hline $\begin{array}{c}X_{1} \text { dan } \\
X_{2}\end{array}$ & - & - & - & 0,539 \\
\hline
\end{tabular}

Sumber: Hasil Pengolahan Data 2016

Berdasarkan Tabel 8 dapat dilihat bahwa adanya pengaruh langsung antara kenyamanan dan kepercayaan konsumen terhadap keputusan pembelian. Pengaruh yang paling besar secara parsial adalah antara kenyamanan $\left(\mathrm{X}_{1}\right)$ terhadap keputusan pembelian (Y) sebesar 0,318, sedangkan kepercayaan konsumen $\left(\mathrm{X}_{2}\right)$ terhadap keputusan pembelian (Y) hanya sebesar 0,221.

Dapat diketahui bahwa total koefisien jalur antara kenyamanan dan kepercayaan konsumen sebesar 0,539 dengan $\mathrm{R}$ square 0,539. Sehingga dapat diketahui nilai dari koefisien residu melalui rumus berikut:

$\mathrm{P}_{\mathrm{Y \varepsilon}}=\sqrt{1-} R_{y(x)}^{2}$

$\mathrm{P}_{\mathrm{Y \varepsilon}}=\sqrt{1-0,539}$ 
$\mathrm{P}_{\mathrm{Y} \varepsilon}=\sqrt{0,461}$

$\mathrm{P}_{\mathrm{Y} \varepsilon}=0,679$

Hasil tersebut menunjukkan bahwa kenyamanan (X) dan kepercayaan konsumen secara simultan mempengaruhi keputusan pembelian (Y) yaitu sebesar 53,9\%. Sedangkan pengaruh dari luar yang tidak diteliti $(0,679)^{2}=$ $0,461 \times 100 \%=46,1 \%$. Sedangkan total pengaruh langsung dan tidak langsung dari Kenyamanan $\left(\mathrm{X}_{1}\right)$ dan kepercayaan konsumen $\left(\mathrm{X}_{2}\right)$ terhadap keputusan pembelian (Y) adalah sebesar 0,539 sehingga dapat diketahui nilai dari koefisien residu melalui rumus berikut:

$\mathrm{P}_{\mathrm{Z \varepsilon}}=\sqrt{1-R_{z(x, y)}^{2}}$

$\mathrm{P}_{\mathrm{Z \varepsilon}}=\sqrt{1-0,539}$

$\mathrm{P}_{\mathrm{Z \varepsilon}}=\sqrt{0,461}$

$\mathrm{P}_{\mathrm{Z \varepsilon}}=0,679$

Hasil tersebut menunjukkan bahwa Kenyamanan dan kepercayaan konsumen memiliki pengaruh yaitu sebesar $53,9 \%$. Sedangkan pengaruh dari luar yang tidak diteliti $(0,679)^{2}=0,461 \times \quad 100 \%=46,1 \%$ dipengaruhi variabel lain yang tidak termasuk kedalam penelitian ini.

Kenyamanan dan kepercayaan menjadi hal yang penting dalam mempengaruhi Keputusan pembelian online. Kualitas dan aksesibilitas toko online, nilai produk atau jasa yang ditawarkan, integrasi umpan balik konsumen, review dan sistem rating merupakan faktor yang termasuk dalam kenikmatan (enjoyment) belanja online, sedangkan kepercayaan konsumen dapat ditentukan oleh kepercayaan dari penjual itu sendiri (Lee Hao et al., 2014). Kenikmatan belanja dapat ditingkatkan melalui jejaring interaktif sesama konsumen yang mengunjungi toko online, hal tersebut dapat mempengaruhi kenikmatan belanja sehingga memprediksi keputusan beli konsumen, sedangkan kepercayaan dilihat dari janji dan komitmen penjual terhadap konsumen yang akan menjadi persepsi positif konsumen dalam proses pembelian (Shirin dan Clara, 2015).

Hasil dari penelitian kepada 165 anggota fan page facebook Blibli.com bahwa pengaruh langsung maupun tidak langsung antara kenyamanan dan kepercayaan konsumen terhadap keputusan pembelian, yang memiliki pengaruh paling besar adalah kenyamanan terhadap keputusan pembelian yaitu 31,8\%\%, dan pengaruh yang kecil yaitu pengaruh kepercayaan konsumen terhadap keputusan pembelian sebesar $22,1 \%$. Hasil secara verifikatif menunjukkan bahwa variabel kenyamanan dan kepercayaan konsumen mempengaruhi minat pembelian sebesar 53,9\%.

\section{KESIMPULAN}

Berdasarkan hasil penelitian di pembahasan dikemukakan kesimpulan sebagai berikut:

Hasil penelitian menyatakan bahwa kenyamanan pada Blibli.com berada pada kategori cukup nyaman. Hal ini menunjukkan bahwa kenyamanan di Blibli.com cukup baik. Dimensi yang memiliki penilaian paling tinggi yaitu consumer empowerment orientation dan intreractivity dengan perolehan skor 6.508 atau sebesar 57,24\%. Sedangkan dimensi yang memiliki penilaian paling rendah yaitu attractiveness dengan perolehan skor 2.424 atau sebesar 21,33\%. Kepercayaan pada Blibli.com berada pada kategori cukup tinggi. Hal ini menunjukkan bahwa kenyamanan di Blibli.com cukup baik. Dimensi yang memiliki penilaian paling tinggi yaitu trusting belief dengan perolehan skor 4.201 atau sebesar 63,19\%. Sedangkan dimensi yang memiliki penilaian paling rendah yaitu trusting intention dengan perolehan skor 2.447 atau sebesar 36,81\%. Pengaruh kepercayaan konsumen terhadap keputusan pembelian pada anggota fan page facebook Blibli.com dapat dilihat dari dimensidimensinya yang terdiri dari trusting intention dan trusting belief yang berada pada kategori cukup tinggi. Temuan tersebut menunjukkan bahwa kepercayaan anggota fan page facebook Blibli.com pada social commerce berjalan dengan cukup baik. Berdasarkan temuan penelitian dimensi trusting belief merupakan dimensi yang memiliki penilaian paling tinggi dalam mempengaruhi keputusan pembelian produk di social commerce. Dimensi integrity yang menjadi nilai tertinggi dikarenakan Blibli.com mampu meyakinkan konsumen untuk menjaga dan memenuhi kesepakatan dalam bertransaksi. Dimensi yang memiliki penilaian paling rendah dalam mempengaruhi keputusan pembelian adalah trusting intention yang menunjukkan bahwa pemberian informasi pribadi kepada penjual, melakukan transaksi, serta bersedia untuk mengikuti saran atau permintaan dari penjual tidak penting dalam transaksi penjualan online dan diartikan bahwa kepercayaan konsumen terhadap feedback akan masukan dan saran dari penjual yang dianggap masih rendah.

Kenyamanan dan kepercayaan konsumen memiliki pengaruh positif terhadap keputusan pembelian dengan pengaruh yang cukup tinggi. Temuan tersebut menunjukan bahwa semakin tinggi penerapan kenyamanan dan kepercayaan konsumen, maka semakin tinggi pula keputusan 
pembelian produk di social commerce pada anggota fan page facebook Blibli.com.

\section{DAFTAR PUSTAKA}

Andrade, E. 2000. Indentiffying discriminating variables of online and offline buyers: a perceived-risk approach. Proceeding of 6th Americas Conference on Information Systems, pp. 1386-1392.

Bruner II GC, Kumar A. 2005. Explaining consumer acceptance of hanheld Internet devices. J Bus Res; 58 (5):553-8

Childers, T.L., Carr, C.L., Peck, J. and Carson, S. 2001, "Hedonic and utilitarian motivations for online retail shopping behavior", Journal of Retailing, Vol. 77 No. 4, pp. 511-35.

Cho, Y,. Im, I,. Hiltz, R., and Fjermestad, J. 2001. Causes and outcomes of online customer complaining behavior: impilications for customer relationship management (CRM). Proceeding of the 7th Americas Conference on Informationn System, pp. 900-907.

Dahlberg T., Mallat, N. Dan Oorni, A. 2003. Trust enchance Technology Acceptance Model-Consumer acceptance of mobile payment solutions. Proceedings of the CIC Rountable.

Elissa, Ingge dan Mujiyana. 2013. Analisis Faktor-Faktor yang Mempengaruhi Keputusan Pembelian Via Internet pada Toko Online. Jurnal Ekonomi Manajemen Universitas Diponegoro.

Gefen, D. dan Straub, D. 2004. "Managing User Trust in B2C e-Services", e-Service Journal,(2): 7-24.

Hendri, Ma'ruf. 2006. Pemasaran Ritel. Jakarta: PT. Gramedia Pustaka Utama.

Janverpaa, S. L., Tractinsky, N., and Vitale, M. 2000. Consumer trust in an internet store. Information Technology and Management (1), pp. 45-71.

Katawetawaraks, Chayapa., dan Wang, Cheng Lu. (2011). Online Shopper Behavior: Influences Of Online Shopping Decision, 1(2). Published by Asian Journal of Business Research.

Kawee Boonlertvanic. 2009. Journal consumer buying \& decision making behavior of a digital camera in Thailand. RU. Int. J. Vol. 3 (1)

Kotler, Philip and GaryArmstrong. 2014.Principles Of Marketing, Harlow: Person Education
Kotler, Philip and Kevin Lane Keller. 2016. Marketing Management $15^{\text {th }}$ Edition United States of America: Pearson Education.

Koufaris M. 2002. Applying the technology Acceptance Model of Flow Theory to Online Consumer Behaviour, Information Systems Research, 13(2), 205-223.

Kwek et al., "Investigating the Shopping Orientations on Online Purchase Intention in the e-Commerce Environment: A Malaysian Study", Journal of Internet Banking and Commerce, August, Vol.15, No.2, 2010

Lee Hao Suan Samuel, Khong Kok Wei dan Hong Jer Lang. 2014. "Influence of Online Shopping Enjoyment and Trust towards Purchase Intention in Social Commerce Sites" ISBN: 978-969-9347-16-0. Handbook on the Emerging Trends in Scientific Research Malaysia.

Lee, J., kim, J., and Moon, J. Y. 2000. What makes internet user visit cyber stores again? Key design factors for customer loyalty. CHI Letters (2:1), pp. 305-312.

Mcknight, Chervany. 2001."Trust And Distrust Definitions: One Bite At A Time.Trust in Cyber-Societies: Integrating the Human and Artificial Perspectives", 27-54.

Seock dan Bailey, 2008. "The Influence of College Students' Shopping Orientations and Gender Differences on Online Information Searches and Purchase Behaviours", International Journal of Consumer Studies. p. 113-121

Schiffman \& Kanuk. (2004). Perilaku Konsumen (edisi 7). Jakarta : Prentice Hall

Schiffman dan Kanuk. 2010. Perilaku Konsumen. Jakarta: PT. INDEK.

Solomon, M., Gary B., Soren A., dan Margaret K.H. 2013. Consumer Behaviour A European Perspective Fifth Edition. Prentice Hall. Financial Times.

Sularto, Lana. 2004. Pengaruh Privasi ,Kepercayaan Dan Pengalaman Terhadap Niat Beli Konsumen Melalui Internet. jurnal Ekonomi \& Bisnis No. 3, Jilid 9, pp138-155.

Majalah Marketing. Edisi 01/XV/Januari 2015 Majalah SWA. XXXI. Edisi 12-25 November 2015

www.blibli.com. Akses: 14:48 WIB.Senin, 1 Ferbruari 2016 